\title{
Comparison of urinary excretion of Deoxypiridinoline and value of serum Osteocalcin within the Knee Osteoarthritis grading
}

\author{
Harry Isbagio
}

\begin{abstract}
Abstrak
Petanda molekuler yang dapat menunjukkan perbedaan dalam derajat progresivitas Osteoartritis (OA) akan memberikan kemudahan bagi penelitian klinik. Deoksipiridinolin (DPD) urin dan osteokalsin (OC) serum telah digunakan secara luas untuk petanda metabolisme tulang, sedangkan penggunaannya sebagai petanda molekuler OA belum banyak data yang mendukung. Berbagai penelitian terdahulu menunjukkan hasil yang saling bertentangan dalam hal eskresi DPD urin dan kadar OC serum pada berbagai derajat OA lutut. Tujuan penelitian ini untuk melihat perbedaan ekskresi DPD urin dan kadar OC serum diantara derajat dari OA lutut. Penelitian ini merupakan studi potong-lintang pada satu kelompok dari 69 pasien OA lutut. Derajat OA ditentukan menurut skala derajat Kellgren dan Lawrence. Kelompok pasien dengan OA lutut derajat 2 dinyatakan sebagai kelompok OA awal dan kelompok pasien dengan derajat 3 dan 4 dinyatakan sebagai kelompok OA lanjut. DPD urin diukur dengan metode Immunochemilunescence dan OC serum menggunakan metode

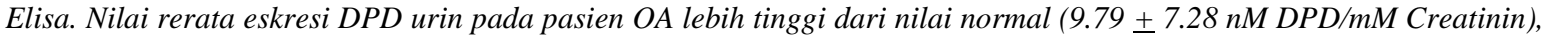
tetapi nilai rerata OC serum dalam batas normal $(8.49+4.68 \mathrm{ng} / \mathrm{mL})$. Tidak ada perbedaan bermakna di antara OA awal dan OA lanjut dalam hal usia, indeks massa tubuh (IMT),lama sakit, eskresi DPD urin dan kadar serum OC. Disimpulkan, pada model penelitian potong lintang ini didapatkan tidak ada perbedaan bermakna dalam hal ekskresi DPD urin dan kadar OC serum di antara derajat OA lutut. Oleh karena hasil dari berbagai penelitian tidak konstan maka penggunaan DPD urin dan serum OC sebagai petanda molekuler untuk progresivitas OA masih memerlukan lagi penelitian prospektif jangka panjang. (Med J Indones 2004; 13: 96-101)
\end{abstract}

\begin{abstract}
The identification of molecular markers, which reflects differences in disease progression rates in Osteoarthritis (OA), would greatly facilitate clinical studies. Urinary Deoxypyridinoline (UDPD) and serum osteocalcin (OC) had been widely used for marker of bone metabolism, but the use for molecular marker in OA was lack of data. Recent studies show that there were conflicted results between urinary excretion of DPD and serum OC value within knee OA grading. The aim of this study is to compare of urinary excretion of DPD and the level of serum OC as destructive parameter of cartilage within the knee OA grading. This cross sectional study comprise of 69 patients with OA of knee joints. Kellgren and Lawrence scale was use for grading of OA. Group of patients with knee OA grade 2 call as group of early OA and group of patients with knee OA grade 3 and 4 calls as group of late OA. DPD in urine was measured using Immunochemilunescence, serum osteocalcin was measured using Elisa method. The mean value of urinary concentrations of DPD in OA patients was higher than normal value (9.79 $\pm 7.28 \mathrm{nM} \mathrm{DPD} / \mathrm{mM}$ Creatinin), and the mean value of serum OC within normal value $(8.49+4.68 \mathrm{ng} / \mathrm{mL})$. There were no significant differences of age, body mass index (BMI), duration of illness, urinary excretion of UDPD and serum OC level between early and late OA. In conclusion, there is no significant difference of urinary excretion of DPD and serum OC level within knee OA grading. The use of urinary DPD and serum OC as molecular markers of progression of OA needed to be explored by other longitudinal study. (Med J Indones 2004; 13: 96-101)
\end{abstract}

Keywords: Knee osteoarthritis, deoxypiridinoline, osteocalcin

The frequency and severity of osteoarthritis (OA) of the knee increases with age. It is generally characterized

Department of Internal Medicine, Faculty of Medicine

University of Indonesia/ Dr.Cipto Mangunkusumo National

Central Hospital, Jakarta, Indonesia by joint space narrowing on X-ray, knee pain, and a loss of joint function. OA is not only characterized by cartilage destruction but also by alteration of bone and synovial tissue metabolism, though their relative importance in the initiation and progression of $\mathrm{OA}$ is still debated. ${ }^{1}$ The most widely used method for radiographic evaluation of OA progression remains 
the Kellgren and Lawrence (KL) grading scale, which has been considered the "gold standard" for diagnosis and assessment of the progression of the condition. ${ }^{2}$ However, when radiological diagnosis is established, significant joint damage has often already occurred. ${ }^{1}$

Under such circumstances, the identification, if possible, of molecular markers in easily sampled body fluids such as blood or urine, which reflect differences in disease progression rates, would greatly facilitate clinical studies. ${ }^{3}$ A good molecular marker should define differences between OA patients and normal individuals. It should also define changes in patient clinical status over time. Biochemical markers are molecules of connective tissue matrices that are released into biological fluid during the process of tissue turnover. Several biochemical markers of bone, cartilage, and synovium have been described in experimental animal models and in humans with OA. ${ }^{4}$

The covalent bridges or cross links between the adjacent molecules of collagen stabilize the extra cellular matrix of connective tissues. Pyridinoline (PYD), a trifunctional 3-hydroxypyridinium crosslink, and its minor analogue, deoxypyridinoline (DPD), are two of the non-reducible cross-links. ${ }^{5}$

Owing to their natural fluorescent properties PYD and DPD have been identified in many connective tissues, essentially in bone and cartilage. DPD is mostly found in bone, while PYD is found both in skeletal and vascular connective tissue. ${ }^{5}$ When collagen fibrils are degraded into molecular fragments as a result osteoclastic resorption, PYD and DPD are released into the circulation. ${ }^{6}$ They are then cleared by the kidney and excreted through urine, where they can be detected in peptide bound and free forms. It has been reported that $40 \%$ of these cross-links are excreted into urine as free and $60 \%$ in the peptide bound form. ${ }^{6}$

Pyridinium cross-links have already been proposed as an index of bone resorption in Paget's disease, primary hyperparathyroidism, bone metastasis and osteoporosis. ${ }^{5}$ PYD and DPD were also investigated in osteoarthritis (OA) and rheumatoid arthritis (RA). They were suggested as markers of joint degradation. $^{7,8}$ There were a study which correlate urinary pyridinium cross-links with the measurement of joint space narrowing in patients with hip OA. ${ }^{5}$ The other study shown the correlation between urinary PYD and DPD with subgroup of knee OA grading. ${ }^{9}$ Another study try to correlate between urinary DPD in different skeletal disease. ${ }^{10}$ However the results of these studies were conflicted.

Osteocalcin (bone Gla protein) is a product of osteoblast, which appears in the serum. The names osteocalcin derives from the abundance of this protein in osseous tissue $(10-20 \%$ of the noncollagenous protein) and its affinity for $\mathrm{Ca}^{2+}$. The levels have been found to correlate with bone turnover using histomorphometric methods. Little is known of levels of osteocalcin in OA although in one study serum and synovial fluid levels were higher in patients with destructive form of the disease compared to subject without evidence of bone destruction. ${ }^{11}$ Another study compare 3 groups of OA, osteoporosis and normal subject found that serum osteocalcin showed no significant differences among the 3 groups of patients. ${ }^{12}$

The aim of this study is to compare of urinary excretion of DPD and the level of serum OC as destructive parameter of cartilage within the knee OA grading.

\section{METHODS}

\section{Subject}

This study is a cross sectional study on a group of patients with OA of knee joints. OA of knee joints was diagnosed on the basis of clinical symptoms, physical examination and radiological findings according to the American College of Rheumatology (ACR) Criteria for Classification of OA of the knee. Antero-posterior weight-bearing knee $\mathrm{X}$-rays were taken, and evaluated according to the Kellgren and Lawrence grading scale. The patients who had grade 0 and 1 were excluded. Patients who had grade 2 at entry of the study entering the first arm of study classified as early OA group and those with grade 3 and 4 entering the second arm and grouped as late OA. Informed consent was obtained from all participants. The procedures followed were in accordance with the principles of the Declaration of Helsinki in 1975, as revised in 1983.

\section{Sample collection, storage and measurement}

Fasting second void urine samples were taken in the morning without any predetermined diet and centrifuged (3000 g) for 10 minutes, and were stored at $-20^{\circ} \mathrm{C}$. All the assays were performed within 2 
weeks of sample collection. Deoxypyridinoline (DPD) in urine was measured using Immunochemilunescence methods with reagent from DPC/Immulite. The value of DPD was expressed per mmol of urinary creatinine. The normal ranges of UDPD is $2.3-5.4 \mathrm{nM}$ $\mathrm{DPD} / \mathrm{mM}$ Creatinin for male and $3.0-7.4 \mathrm{nM}$ $\mathrm{DPD} / \mathrm{mM}$ creatinin for female. Serum osteocalcin was measured using Elisa method with reagent from Metra bio System. The normal value for male is 3.4-9.1 $\mathrm{ng} / \mathrm{mL}$ and female is $3.7-10 \mathrm{ng} / \mathrm{mL}$.

\section{Statistical analysis}

A comparison of variables between two groups was performed using independent-samples t-test and chisquare test. A Regression linier model was used for looking the differences between two groups

\section{RESULT}

There were 69-study subject fulfilled the inclusion criteria of this study. The majority of the patients were female $(68.15 \%)$ and the mean of the age were 60.32 \pm 7.91 year. There were 38 patients of early knee OA and 31 patients of late OA. The mean of duration of illness was $54.34 \pm 63.35$ months. Most of the patient had high body mass index (overweight and obese). The mean value of urinary concentrations of DPD in OA patients were higher than normal value $(9.79 \pm$
$7.28 \mathrm{nM} \mathrm{DPD} / \mathrm{mM}$ creatinin), and the mean serum OC level within normal value $(8.49 \pm 4.68 \mathrm{ng} / \mathrm{mL})$.

If the patient divided into the category of normal result $(=\mathrm{Nr}$ ) and abnormal result (higher than normal $=\mathrm{H}$ ) of the OC and DPD, we found there were 36.76 $\%$ for OC and $61.01 \%$ for DPD is categorized as higher. The baseline patient characteristics as can be seen in Table 1.

Due to the distribution of duration of illness and urinary DPD were abnormal, for statistical manners we are using logarithmic analysis (log duration of illness and log DPD urine) to normalize the curve, so the data could be calculated.

There were no significant differences of age, body mass index (BMI), duration of illness, urinary excretion of DPD and value of serum OC between early and late OA. The result could be found on Table 2 .

Although further analisys was made by cathegorized the OC level and UDPD as $\mathrm{N}$ or $\mathrm{H}$, there is still no different between the two groups of knee OA. (Refer to Table 3 for statistic analysis).

If we looked at UDPD and serum OC level by sex differences, only UDPD showed statistically significantly different $(\mathrm{p}<0.001)$ between male and female. See Table 4 for more details calculation.

Table 1. Baseline characteristic of the subject $(n=69)$

\begin{tabular}{lccc}
\hline & Grade 2 & Grade $3+4$ & Total \\
\hline$n$ & 38 & 31 & 69 \\
Age & $59.0 \pm 8.44$ & $61.94 \pm 7.02$ & $60.32 \pm 7.91$ \\
Sex Ratio M/F & $14 / 24$ & $8 / 23$ & $22 / 47$ \\
Duration of Illness & $35.38 \pm 47.59$ & $72.47 \pm 71.70$ & $54.24 \pm 63.35$ \\
BMI & $25.13 \pm 3.40$ & $26.07 \pm 4.34$ & $25.55 \pm 3.85$ \\
Serum OC (n=68) & $8.15 \pm 4.71$ & $8.92 \pm 4.68$ & $8.49 \pm 4.68$ \\
DPD Urine $(\mathrm{n}=59)$ & $10.59 \pm 9.01$ & $8.79 \pm 4.14$ & $9.79 \pm 7.28$ \\
Category OC Nr/H & $26 / 12$ & $17 / 13$ & $43 / 25$ \\
Category DPD Nr/H & $12 / 21$ & $21 / 15$ & $33 / 36$ \\
\hline
\end{tabular}

Table 2. A Comparison of Age, Duration of illness, Body Mass Index, Serum Osteocalcin and Urinary Deoxypyridinoline between subgroup of knee $\mathrm{OA}^{*}$

\begin{tabular}{lcccc}
\hline & Grade 2 & Grade $3+4$ & p & $95 \%$ C.I. \\
\hline Age & $59.0 \pm 8.44$ & $61.94 \pm 7.02$ & 0.126 & $-6.72 ; 0.85$ \\
Log Duration of Illness & $1.26 \pm 0.56$ & $1.57 \pm 0.62$ & 0.052 & $-0.627 ; 2605 \mathrm{E}-03$ \\
BMI & $25.13 \pm 3.40$ & $26.07 \pm 4.34$ & 0.320 & $-2.797 ; 0.927$ \\
Serum OC & $8.15 \pm 4.71$ & $8.92 \pm 4.68$ & 0.502 & $-3.069 ; 1.517$ \\
Log DPD Urine & $0.84 \pm 0.20$ & $0.91 \pm 0.17$ & 0.229 & $-0.163 ; 4.005 \mathrm{E}-02$ \\
\hline
\end{tabular}

* Independent-samples t-test was used for comparing the means. 
Table 3. A Comparison of Categorized serum Osteocalcin and Urine Deoxypyridinoline as Normal or High between sub group of knee OA

\begin{tabular}{|c|c|c|c|c|c|}
\hline \multirow[b]{2}{*}{ Category } & & \multicolumn{2}{|c|}{ Category of Knee OA } & \multirow[b]{2}{*}{ Total } & \multirow[b]{2}{*}{$p$} \\
\hline & & Grade 2 & Grade $3+4$ & & \\
\hline Category of serum & Normal & $26(60.5 \%)$ & 17 (39.5\%) & $43(100 \%)$ & \multirow{3}{*}{$p=0.316$} \\
\hline \multirow[t]{2}{*}{ Osteocalcin } & High & $12(48.0 \%)$ & $13(52.0 \%)$ & $25(100 \%)$ & \\
\hline & Total & 38 (55.9\%) & $30(44.1 \%)$ & $68(100 \%)$ & \\
\hline Category of urinary & Normal & $12(52.2 \%)$ & $11(47.8 \%)$ & $23(100 \%)$ & \multirow{3}{*}{$p=0.642$} \\
\hline \multirow[t]{2}{*}{ Deoxypiridinoline } & High & $21(58.3 \%)$ & $15(41.7 \%)$ & $36(100 \%)$ & \\
\hline & Total & $33(55.9 \%)$ & $26(44.1 \%)$ & $59(100 \%)$ & \\
\hline
\end{tabular}

* Statistical method: Chi-square test

Table 4. A Comparison of Age, Duration of illness, Body Mass Index, Serum Osteocalcin and Urinary Deoxypyridinoline between male and female*

\begin{tabular}{lcccc}
\hline & Male & Female & p & 95\% C.I. \\
\hline Age & $61.73 \pm 7.89$ & $59.66 \pm 7.92$ & 0.315 & $-6.15 ; 2.01$ \\
Log Duration of Illness & $1.32 \pm 0.59$ & $1.46 \pm 0.62$ & 0.381 & $-0.192 ; 0.495$ \\
BMI & $24.90 \pm 2.70$ & $25.86 \pm 4.28$ & 0.340 & $-1.032 ; 2.946$ \\
Serum OC & $8.99 \pm 4.78$ & $8.26 \pm 4.67$ & 0.549 & $-3.170 ; 1.700$ \\
Log DPD Urine & $0.74 \pm 0.15$ & $0.94 \pm 0.17$ & $<0.001$ & $-.102 ; 0.288$ \\
\hline
\end{tabular}

* Compare means of independent-samples t-test

\section{DISCUSSION}

Biochemical markers of bone and/or cartilage remodeling have been proposed as potential tools for the diagnosis of OA. An increase in serum or urine concentrations of serum cartilage oligomeric matrix protein (COMP), ${ }^{13,14}$ serum keratan sulfate (KS), ${ }^{15}$ serum hyaluronic acid (HA) ${ }^{16}$ and urine PYD and $\mathrm{DPD}^{17}$ was described in patients with OA.

The increase of urinary excretion of PYD and DPD in OA had been reported in several studies. Mac Donald et al found a higher urinary excretion of PYD in gonOA than in cox-OA and poly-OA. ${ }^{18}$ Astbury et al demonstrated that the urinary excretion of pyridinium cross-link could be related to joint damaged. ${ }^{19}$ In our study not all of the cases increased urinary excretion of DPD, only $61.01 \%$ of the cases excreted DPD more than normal value. However the mean and standard deviation of urinary DPD $(9.79 \pm 7.28$ $\mathrm{DPD} / \mathrm{mM}$ Creatinin) was higher than normal value (table 1). This study support the previous study on urinary excretion of DPD as higher in OA.

On the other hand Graverand et al. ${ }^{5}$ found only in Rheumatoid Arthritis (RA) that UDPD excretion was increased DPD,but not in hip-OA, nor knee-OA and poly-OA. The same result reported by Müller et al ${ }^{10}$ shows that in adults, patients with RA have the highest levels of free and peptide bound forms of PYD and DPD. In OA and Psoriatic Arthritis, no significant differences were found between free PYD and total PYD, as compared with healthy adult. The differences between our results with those studies may be due to the selection of OA patients, which is limited to OA of the knee joint only.

The urinary excretion of DPD is similar in men and pre-menopausal women. An increased excretion of DPD in peri and post-menopausal women compared with men was demonstrated in other study, ${ }^{20}$ these findings similar with our study. (Table 4) However all of women in our study was post-menopausal women as we are aware that the selection of cases may influenced the result.

The present study (Table 2 and Table 3) does not support the findings of MacDonald et ${ }^{18}$ al that demonstrates DPD excretion increased significantly with the radiological stage of OA. Takahashi et $\mathrm{al}^{9}$ were compared between grade 1-2 OA of the knee with grade $3-4$, found that the group with grade 3-4 
had significantly greater value of urinary excretion of total PYD, peptide and total DPD.

However in other studies, one of them found that urinary excretion of PYD and DPD clearly increased with the increasing of radiographic score in Hip OA and Knee OA patient, but the difference between the four groups was not significant. ${ }^{5}$

Our findings (Table 2) is different with those study may be due to relatively small number of our patients, so in late stage of OA (grade $3+4$ ) the logarithmic urinary excretion of DPD (log DPD) relatively higher but not significantly different with early stage of OA (grade 2). The other explanation for this findings was the used of Kellgren-Lawrence score. This score is widely used for OA studies and is simple but may sometimes lack accuracy. ${ }^{21}$ Another more accurate and more reliable method than scores to evaluate OA severity is measuring JSW. It can be measured manually (with a caliper, graduated plastic ruler, or graduated magnifying lens) or with a computer after digitization of the radiographs. ${ }^{21}$

Urinary pyridinoline cross-links have been extensively studied as markers of RA and OA. DPD could be considered as a sensitive marker of bone degradation since it is mostly found in bone and dentine and the turnover of the latter tissue are negligible. PYD is a major collagen crosslink in bone and cartilage and other connective tissues such as muscle and intervertebral discs.

Although bone resorption is probably the major source of urine hydroxypyridinium crosslink, the PYD: DPD ratio may help to define collagen degradation in cartilage relative to other tissues. In patients with advanced OA both PYD and DPD were significantly increased and the PYD: DPD ratio was also unchanged. Thus most probably the observed increased excretion of pyridinium crosslink in patients with late OA reflects the bone erosion and/or the increased sclerotic bone remodeling of joint epiphysis that occurs in the advanced stages of OA The unchanged excretion of PYD and DPD in earlier stage OA suggests that the markers certainly do not reflect collagen degradation of the articular cartilage. ${ }^{5}$

On the other hand, there was a theory to explain the absence of an increase of urinary excretion of DPD and PYD in late stage of OA. ${ }^{9}$ This theory says that the absence of an increase in bone resorption might be related to the pathogenesis of osteoarthritic changes of bone, such as osteophytes and a subchondral sclerosis. Several studies have shown the elevated bone mineral density in OA. ${ }^{22}$ There is a study demonstrates that spinal OA is associated with a generalized increase in bone mineral density and a decreased excretion of collagen cross-links. It suggests that spinal OA may be mediated by decreased bone turnover. In accordance with study of spinal OA, our observation found that there was not highly increase of bone resorption's markers.

Garnero and colleagues ${ }^{1}$ reported that within the biochemical markers measured at baseline (include serum OC level and other markers) the increasing urinary type II collagen C-telopeptide and glucosylgalactosyl PYD were the only ones that correlated with cartilage loss assessed by joint space area. The absence of correlation between JSW and OC, COMP, or HA is consistent with those observed in Bruyere et al study. ${ }^{23}$ Some elements may explain why these molecular markers did not correlate with JSW. JSW is only an indirect measure of cartilage volume and does not take into account other components of OA severity like the subchondral bone. Further, none of these molecular markers are unequivocally cartilagespecific. OC, PYD and DPD are markers more specific for bone turnover. Our study similar with those studies that there were no significant different between the excretion of UDPD and the value of serum OC with the grading of knee OA. Bruyere et $\mathrm{al}^{23}$ reported that 1-year changes in OC and HA were correlated with 3-year progression in mean and minimal JSW. So a more severe joint space narrowing after 3 years could be predicted by a greater increase in OC or a greater decrease in HA after 1 year. Progression of knee OA is characterized by phases of disease activity that involve the cartilage, bone, and synovium. Those results suggest that a higher level of bone remodeling, evidenced by a short-term increase in the level of OC, could be predictive of long-term cartilage loss. The Bruyere study was one of few long-term studies that assessed the relationship between structural severity of OA and biochemical markers, most of other studies were cross-sectional.

A number of candidate molecular markers (MM) have been identified. The MM that has so far been examined can be classified into two types, skeletal and inflammation markers. Skeletal markers are related to changes in cartilage or bone metabolism. Disease markers are related to inflammation. There were many candidates for skeletal marker for OA; one of this was Cartilage matrix protein (COMP), which could be a promising candidate. ${ }^{14}$ Measurements of 
the serum levels of COMP have potential as means for evaluation of tissue changes in individuals with long standing knee pain in relation to early stages of OA. ${ }^{24}$ Urinary DPD and serum OC could be classified as skeletal markers. Although these markers had been widely used for marker of bone metabolism, they were not yet become a promising candidate for skeletal marker for OA.

In conclusion, in this cross sectional model, there were no significant differences of urinary excretion of DPD and serum OC level within knee OA grading. The use of urinary DPD and serum OC as molecular markers of progression of OA were needed more other longitudinal study.

\section{Acknowledgement}

This work was a part of study which supported by grant of Riset Pembinaan Ilmu Pengetahuan dan Teknologi Kedokteran (Risbin Iptekdok) Ministry of Research and Technology Republic of Indonesia 1997.

\section{REFERENCES}

1. Garnero P, Piperno M, Gineyts E, Christgau S, Delmas $\mathrm{PD}$, Vignon E. Cross sectional evaluation of biochemical markers of bone, cartilage, and synovial tissue metabolism in patients with knee osteoarthritis: relations with disease activity and joint damage. Ann Rheum Dis 2001; 60:619-26.

2. Sharma L.Epidemiology of Osteoarthritis. In: Moskowitz RL, Howell DS, Altman RD, et al,editors. Osteoarthritis. Diagnosis and Medical/Surgical Management. 3rd ed., Philadelphia,WB Saunders,2001,p.3-27.

3. Otterness IG, Swindell AC, Zimmere RO, Poole AR, Ionescus $\mathrm{M}$, Weiner $\mathrm{E}$. An analysis of 14 molecular markers for monitoring osteoarthritis: segregation of the markers into clusters and distinguishing osteoarthritis at baseline. Osteoarthritis Cartilage. 2000; 8:180-5

4. Garnero P, Rousseau J-C, Delmas P. Molecular basis and clinical use of biochemical markers of bone, cartilage and synovium in joint diseases. Arthritis Rheum 2000; 43:953-61

5. Graverand MPHL, Tron AM, Ichou M, Dallard MC, et al. Assessment of urinary hidroxypyridinium cross-links measurement in osteoarthritis. $\mathrm{Br} \mathrm{J}$ Rheumatol 1996; 35:1091-5

6. Knott L, Bailey AJ. Collagen cross-links in mineralizing tissues: a review of their chemistry, function, and clinical relevance. Bone 1998; 22:181-7.

7. Thompson PW, Spector TD, James IT, Henderson E ,Hart DJ. Urinary collagen crosslinks reflect the radiographic severity of knee osteoarthritis Br J Rheumatol 1992; 31:759-61

8. Kaufmann J, Mueller A, Voigt A, Carl HD, Gursche A, Zacher J, Stein G, Hein G. Hydroxypyridinium collagen crosslinks in serum, urine, synovial fluid and synovial tissue in patients with rheumatoid arthritis compared with osteoarthritis. Rheumatology (Oxford) 2003; 42:314-29

9. Takahashi M, Suzuki M, Naitou K, Miyamoto S, Kushida $\mathrm{K}$. Comparison of free and peptide-bound pyridinoline cross-links excretion in rheumatoid arthritis and osteoarthritis. Rheumatology (Oxford) 1999; 38:133-8.

10. Muller A, Jakob K, Hein GE. Evaluation of free and peptide bound collagen crosslink excretion in different skeletal diseases.Ann Rheum Dis. 2003; 62(1):65-7.

11. Campion CV, Delmas PD, Dieppe PA.Serum and synovial fluid osteocalcin (bone gla protein) levels in joint diseas. Br J Rheumatol 1989; 28:393-8.

12. Stewart A, Black A, Robins SP, Reid DM. Bone density and bone turnover in patients with osteoarthritis and osteoporosis. J Rheumatol. 1999 ;26(3):622-6.

13. Clark AG, Jordan JM, Vilim V, et al. Serum cartilage oligomeric matrix protein reflects osteoarthritis presence and severity: the Johnson County Osteoarthritis Project. Arthritis Rheum 1999;42:2356-64

14. Vilim V, Vytasek R, Olejorava M, et al. Serum cartilage oligomeric matrix protein reflects the presence of clinically diagnosed synovitis in patients with knee osteoarthritis. Osteoarthritis Cartilage 2001; 9:612-8.

15. Campion GV, McCrae F, Schnitzer T, Lenz ME, Dieppe PA, Thonar EJ-MA. Levels of keratan sulfate in the serum and synovial fluid of patients with osteoarthritis of the knee. Arthritis Rheum 1991;34:1254-9.

16. Goldberg RL, Huff JP, Lenz ME, Glickman P, Katz R, ThonarEJ-MA. Elevated plasma levels of hyaluronate in patients withosteoarthritis and rheumatoid arthritis. Arthritis Rheum 1991;34:799-807.

17. Thompson PW, Spector TD, James IT, Henderson E, Hart DJ.Urinary collagen crosslinks reflect the radiographic severity of kneeosteoarthritis. BMJ 1992;31:759-61.

18. MacDonald AG, Mac Henry P, Robins SP, Reids DM. Relationship of urinary pyridinium crosslinks to disease extent and activity in oateoarthritis. $\mathrm{Br} \mathrm{J}$ rheumatol 1994;33:16-9

19. Astbury C, Bird HA, MacLaren AM, Robins SP. Urinary excretion of pyridinium crosslinks of collagen correlated with joint damage in arthritis. Br J Rheumatol 1994; 33:11-5

20. Uebelhart D, Schlemmer A, Johansen JS, Gineyts E, Christiansen C, Delmas PD. Effect of menopause andhormone replacement therapy on the urinary excretion of pyridinium crosslinks. J Clin Endocrinol Metab 1991:72:367-73

21. Vignon E, Conrozier T, Piperno M, Richard S, Carrillon Y, Fantino O. Radiographic assessment of hip and knee osteoarthritis.Recommendations: recommended guidelines. Osteoarthritis Cartilage 1999;7:434-6.

22. Peel NFA, Barrington NA, Blumsohn A, Colwell A, Hannon R, Eastell R. Bone mineral density and bone turnover in spinal osteoarthritis. Ann Rheum Dis 1995;54:867- 71 .

23. Bruyere O, Collete JH, Ethgen O, Rovati LC, Giacoveli $\mathrm{G}$, et al. Biochemical markers of bone and cartilage remodeling in prediction of longterm progression of knee osteoarthritis. J Rheumatol 2003; 30:1043-50

24. Petersson IF, Boegard T, Dahlstrom J, Svensson B, Heinegard, Saxne T.Bone scan and serum markers of bone and cartilage in patients with knee pain and osteoarthritis. Osteoarthritis Cartilage 1998; 6:33-39 